\title{
The Research on the Construction of Maturity Model of Project Management in the National Defense Research Institute based on the Grey Multi-level Theory
}

\author{
Wu Wenchuan ${ }^{1, a}$, Bai Sijun ${ }^{2, b}$ \\ ${ }^{1,2}$ Northwestern Polytechnical University,Xi'an 710072,China \\ ajohnwwc@nwpu.edu.cn, bbaisj@nwpu.edu.cn
}

Keywords: National Defense Research Institute. Project Management (PM). Maturity Model. Multi-level Grey Theory.

\begin{abstract}
In this paper, the author design the evaluation index system of project management (PM) in the National Defense Research Institute, and build the Project Management Maturity Mode in the National Defense Research Institute based on the Grey Multi-level Comprehensive Evaluation Theory. This model provides both methods of evaluating the ability levels of PM as well as reference ideas for continuously improving the ability for the sake of the National Defense Research Institute.
\end{abstract}

\section{Introduction}

As a national strategic industry, Science and Technology Industry of National Defense is a critical component of the national advanced manufacturing industry, and the National Defense Research Institute is the core sci-tech force of the national strategic industry. In recent years, as an advanced management mode, PM has been widely used in the research and development projects of the National Defense Research Institute. Years of experience have proved that PM is a kind of advanced management method that is suitable for the National Defense Research Institute. However, with the development of science and technology, the national defense research projects have presented new features - greater complexity and uncertainty, extensive adoption of R \& D models, bigger challenges faced by the scientific research Institute in management coordination and so forth. Confronted with the new features and problems, the National Defense Research Institute must have a good command of their ability and level of PM objectively and accurately, namely the maturity degree of PM. In order to provide scientific basis for the continuous, specific improvement of the ability and level of PM, it is necessary to find out the self-deficiencies in PM. Consequently, it is an urgent issue to establish the maturity evaluation system of PM in our National Defense Research Institute.

The development and application of the Project Management Maturity Model (PMMM) [1] can provide reference for solving the problems above. As an evaluation method to measure an organization's ability to use PM, PMMM was first developed by the Software Engineering Research Institute (SEI) of the Carnegie Mellon University in 1987. PMMM provides a tool for an organization to evaluate PM capabilities. Instead of a simple mathematical analysis or graph, it is a whole set of scientific systems and methods, and a process of leading an organization's PM ability from low to high level as well as increasing the success rate of project implementation. Based on the research results of PMMM and the characteristics of the National Defense Research Institute, this paper intends to build the PMMM of the National Defense Research Institute and apply it to the evaluation and continuous improvement of the PM ability.

\section{Construction and Weight Determination of the Maturity Evaluation Index System of Project Management in the National Defense Research Institute}

According to scientificity, systematicalness, objectivity, operability, hierarchy, qualitative and quantitative combination of six principles, the author mainly refers to PM knowledge system, 
evaluation model of scientific research and production management (CAST) and plenty of pertinent documents, and builds the evaluation index system of PM maturity in the National Defense Research Institute, in combination with real PM of the National Defense Research Institute. In the first place, the authors divides the PM of the National Defense Research Institute into four processes, project start-up, project plan, project execution and control, and project closure. The four processes are used as the second class of evaluation index system. Simultaneously, as the National Defense Research Institute attaches greater importance to multi-project management, another comprehensive PM ability as a second class index is added in this paper. Thus the evaluation index system of PM maturity in this paper covers five second class indexes, including the capability of project start-up, project plan, project execution and control, and project closure, and the comprehensive PM. Under the five second class indexes, corresponding third class index is established. In this way, the evaluation index system of PM maturity in the National Defense Research Institute is preliminarily established.

Then the author adopts the method of fuzzy preference relation in group decision-making[2]. In cooperation with Xi'an Huading Project Management consulting company, the author invited four experts who have been worked in the management of the national defense scientific research projects from International Project Manager Certification (IPMP) appraisers and students who have achieved IPMP B level or C level. These four experts made a selection of the preliminary evaluation index system. The top $60 \%$ of third class indexes is chose as the final. Accordingly, the final evaluation index system is determined.

Ultimately, the analytic hierarchy process (AHP)[3] is employed to weight the evaluation indexes. The author invited ten experts in national defense science and technology to make a comparison between these evaluation indexes, and attained several multi-level judgment matrixes. The weights of each index are established by means of MATLAB to calculate the eigenvalues and eigenvectors of each judgment matrix as well as the consistency check. Considering the length, the index selection and weight calculation will not be detailed specifically.

The Maturity Evaluation Index System of Project Management in the National Defense Research Institute is shown in Table 1.

Table 1: The Final Maturity Evaluation Index System of Project Management in the National Defense Research Institute and its Weight

\begin{tabular}{|c|c|c|c|c|}
\hline $\begin{array}{l}\text { First-class } \\
\text { Index }\end{array}$ & $\begin{array}{l}\text { Second-class } \\
\text { Index }\end{array}$ & Weight & Third-class Index & $\begin{array}{l}\text { Weig } \\
\text { ht }\end{array}$ \\
\hline \multirow{11}{*}{$\begin{array}{l}\text { The Maturity } \\
\text { of PM in the } \\
\text { National } \\
\text { Defense } \\
\text { Research } \\
\text { Institute }\end{array}$} & \multirow{6}{*}{$\begin{array}{l}\text { Project start-up } \\
\text { capability A }\end{array}$} & \multirow{6}{*}{0.262} & $\begin{array}{l}\text { Adequacy of the analysis on the military } \\
\text { demand of project Ca1 }\end{array}$ & 0.076 \\
\hline & & & $\begin{array}{l}\text { Feasibility level of project technology } \\
\text { Ca2 }\end{array}$ & 0.076 \\
\hline & & & $\begin{array}{l}\text { Scientificity of preparation of bidding } \\
\mathrm{Ca} 3\end{array}$ & 0.034 \\
\hline & & & Wining rate of project Ca4 & 0.550 \\
\hline & & & $\begin{array}{l}\text { Approval rate of the annual draft plan of } \\
\text { project Ca5 }\end{array}$ & 0.076 \\
\hline & & & $\begin{array}{l}\text { Correctness of the analysis on main } \\
\text { operational performance Ca6 }\end{array}$ & 0.187 \\
\hline & \multirow{5}{*}{$\begin{array}{l}\text { Project plan } \\
\text { capability B }\end{array}$} & \multirow{5}{*}{0.063} & $\begin{array}{l}\text { Scientificity of the schedule } \\
\text { management } \mathrm{Cb} 1\end{array}$ & 0.128 \\
\hline & & & $\begin{array}{l}\text { Rationality of the data table about } \\
\text { resource requirement Cb2 }\end{array}$ & 0.015 \\
\hline & & & $\begin{array}{l}\text { Rationality of contract management and } \\
\text { planningCb3 }\end{array}$ & 0.031 \\
\hline & & & $\begin{array}{l}\text { Approval rate for the base plan on } \\
\text { project expense Cb4 }\end{array}$ & 0.128 \\
\hline & & & $\begin{array}{l}\text { Completeness of the quality assurance } \\
\text { plan Cb5 }\end{array}$ & 0.240 \\
\hline
\end{tabular}




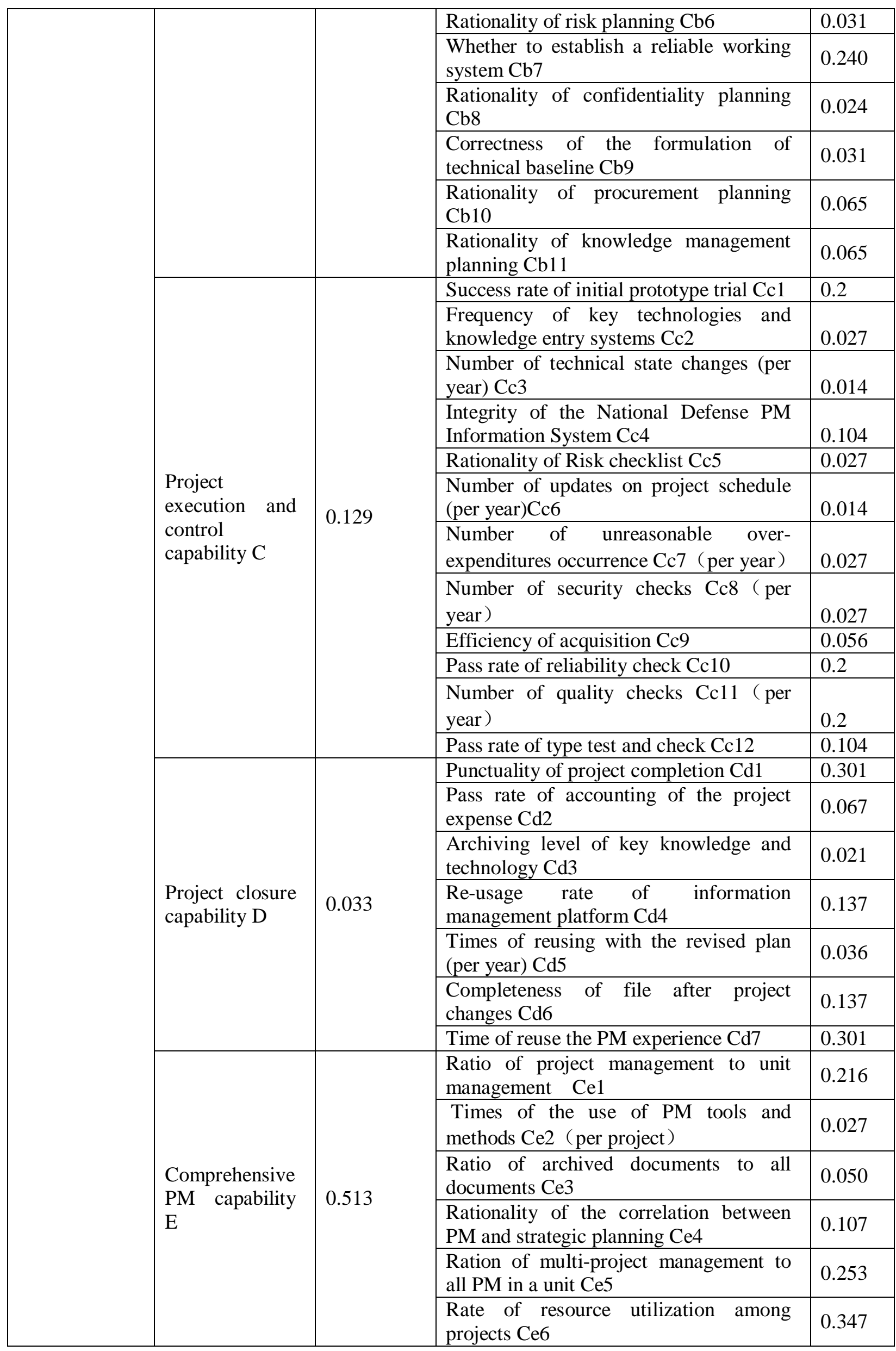




\section{Rank of the maturity of PM in National Defense Research Institute}

The rank of maturity of PM refers to an organization's ability to successfully and reliably implement projects in accordance with predetermined goals and conditions. In other words, there are several well-defined platforms characterizing the PM maturity in an enterprise or an organization during the process of gradual maturation[4]. According to the practice of PM maturity ranks, this paper divides the maturity rank into four. The first is the lowest and the fourth is the highest (see Figure 1). The features of each rank are as follows:

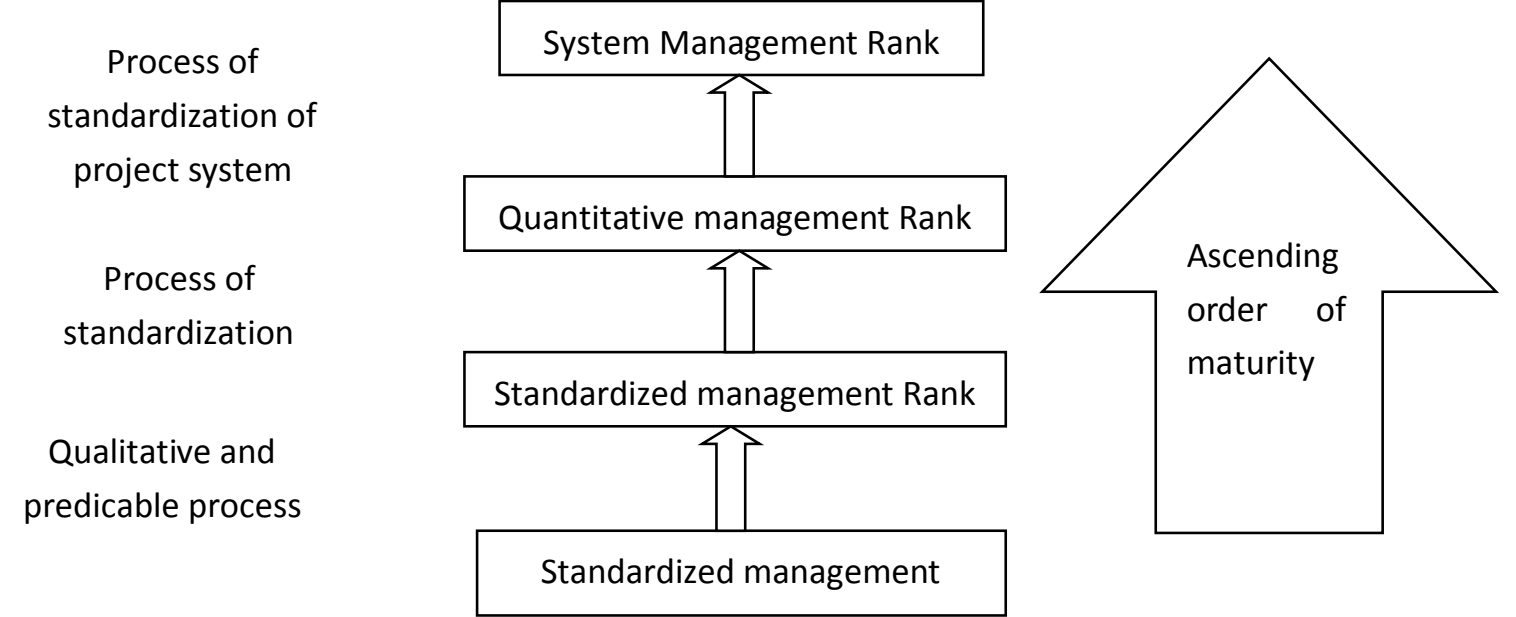

Figure 1 The Rank of Maturity

\section{Rank 1: Standardized management Rank}

Certain standardized PM systems have been established within the organization; The basic PM process established are not universal which is usually used in the management of typical projects in an enterprise; Management support and encouragement on applications; Progress forecasts, arrangements, etc. based on expertise as well as common tools; In most time, single project is centered. This mature level of organization has established a basic PM process to track the cost, schedule and quality.

\section{Rank 2: Standardized management Rank}

Clarified classification as well as standardized process of projects; established the standardized; institutionalized management process; properly thorough information about management; established baseline and informal data collection; details on progress forecasts and arrangements based on industrial standards and organizations; more focus on the organization; implementation of informal analysis of project performance. At this rank, management activities and processes are documented, standardized, and integrated into the organization's standard process, forming a standardized workflow.

\section{Rank 3: Quantitative management Rank}

The visualized PM tools are widely applied; the fixed, formal analysis on project performance is implemented; the progress forecasts, arrangements, etc. are usually based on organizational details; the decision is made through data. At this rank, the organization collects detailed measures of PM processes and product quality, and both the PM processes and products are under quantitative control.

\section{Rank 4: System Management Rank}

The management process is more systematic, focusing on measuring the efficiency and effectiveness of the project, which forms the continuously improved knowledge base; the idea of enterprise PM is universally applied; concerning the conflict and coordination of multi-project management, much more attention is paid to the maximization of enterprise's overall benefit. A 
certain process is used to improve project performance, and the focus of management is on the organizational strategy and the continuous increase of its PM level.

\section{Evaluation Standards of PM maturity in the National Defense Research Institute}

In the evaluation index system of PM maturity, the evaluation criteria of index values should be a crucial link. Based on the characteristics of the PM of China's National Defense Research Institute, this paper adopts the quaternary grading method to evaluate the five processes and 42 evaluation indexes on the basis of document research, analysis and questionnaire survey. The formulated evaluation criteria are shown in Table 2.

Table 2: Evaluation Standards of PM maturity in the National Defense Research Institute

\begin{tabular}{|c|c|c|c|c|c|}
\hline \multirow[b]{2}{*}{ Criteria } & \multirow[b]{2}{*}{ Index } & \multicolumn{4}{|c|}{ Evaluation criteria } \\
\hline & & $\begin{array}{l}\text { Rank 1 } \\
\text { Standardize } \\
\text { d } \\
\text { managemen } \\
\text { t Rank } \\
\end{array}$ & $\begin{array}{l}\text { Rank } 2 \\
\text { Standardize } \\
\text { d } \\
\text { management } \\
\text { Rank } \\
\end{array}$ & $\begin{array}{l}\text { Rank 3 } \\
\text { Quantitativ } \\
\text { e } \\
\text { managemen } \\
\text { t Rank } \\
\end{array}$ & $\begin{array}{l}\text { Rank } 4 \\
\text { System } \\
\text { Management } \\
\text { Rank }\end{array}$ \\
\hline \multirow{6}{*}{$\begin{array}{l}\text { Project } \\
\text { start-up } \\
\text { capabil } \\
\text { ity }\end{array}$} & $\begin{array}{l}\text { Adequacy of the } \\
\text { analysis on the military } \\
\text { demand of project Ca1 }\end{array}$ & $\begin{array}{l}\text { Simple } \\
\text { demand } \\
\text { analysis }\end{array}$ & $\begin{array}{l}\text { Analyzed by } \\
\text { invited } \\
\text { experts }\end{array}$ & $\begin{array}{l}\text { Analysis } \\
\text { after } \\
\text { research }\end{array}$ & \begin{tabular}{l}
\multicolumn{2}{l}{ Appointed } \\
experts do the \\
analysis after \\
research
\end{tabular} \\
\hline & $\begin{array}{l}\text { Feasibility level of } \\
\text { project technology Ca2 }\end{array}$ & $\begin{array}{l}\text { Simple } \\
\text { research on } \\
\text { feasibility }\end{array}$ & $\begin{array}{l}\text { Finished by } \\
\text { invited } \\
\text { experts }\end{array}$ & $\begin{array}{l}\text { Detailed } \\
\text { research on } \\
\text { feasibility }\end{array}$ & $\begin{array}{l}\text { Inclusive } \\
\text { technology, } \\
\text { economy, } \\
\text { strategy etc. }\end{array}$ \\
\hline & $\begin{array}{l}\text { Scientificity of } \\
\text { preparation of bidding } \\
\text { Ca3 }\end{array}$ & $\begin{array}{l}\text { Clear and } \\
\text { organized }\end{array}$ & $\begin{array}{l}\text { Full } \\
\text { formatted } \\
\text { and } \\
\text { documented } \\
\end{array}$ & $\begin{array}{l}\text { Highlighted } \\
\text {, attractive }\end{array}$ & $\begin{array}{l}\text { Agreement } \\
\text { between the bid } \\
\text { and the strategic } \\
\text { function }\end{array}$ \\
\hline & $\begin{array}{l}\text { Wining rate of project } \\
\text { Ca4 }\end{array}$ & $\begin{array}{l}\geq 10 \% \\
\quad\langle 25 \%\end{array}$ & $\geq 25 \%,\langle 40 \%$ & $\begin{array}{l}\geq 40 \% \\
\langle 55 \%\end{array}$ & $\geq 55 \%$ \\
\hline & $\begin{array}{l}\text { Approval rate of the } \\
\text { annual draft plan of } \\
\text { project Ca5 }\end{array}$ & $\begin{array}{l}\geq 60 \%, \\
\langle 70 \%\end{array}$ & $\geq 70 \%,\langle 80 \%$ & $\begin{array}{l}\geq 80 \% \\
\langle 90 \%\end{array}$ & $\geq 90 \%$ \\
\hline & $\begin{array}{l}\text { Correctness of the } \\
\text { analysis on main } \\
\text { operational } \\
\text { performance } \mathrm{Ca} 6\end{array}$ & $\begin{array}{l}\text { Simple } \\
\text { analysis }\end{array}$ & $\begin{array}{l}\text { Equipped } \\
\text { with formal } \\
\text { analysis } \\
\text { document }\end{array}$ & $\begin{array}{l}\text { Full } \\
\text { formatted } \\
\text { and } \\
\text { documente } \\
\text { d }\end{array}$ & $\begin{array}{l}\text { Highlighted, } \\
\text { reasonable } \\
\text { analysis }\end{array}$ \\
\hline \multirow{5}{*}{$\begin{array}{l}\text { Project } \\
\text { plan } \\
\text { capabil } \\
\text { ity }\end{array}$} & $\begin{array}{l}\text { Scientificity of the } \\
\text { schedule management } \\
\text { Cb1 }\end{array}$ & $\begin{array}{l}\text { Formal } \\
\text { planning } \\
\text { document }\end{array}$ & $\begin{array}{l}\text { Plan-making } \\
\text { procedurally }\end{array}$ & $\begin{array}{l}\text { Proper use } \\
\text { of tools }\end{array}$ & $\begin{array}{l}\text { Reasonable } \\
\text { prediction on } \\
\text { working time }\end{array}$ \\
\hline & $\begin{array}{l}\text { Rationality of the data } \\
\text { table about resource } \\
\text { requirement Cb2 }\end{array}$ & $\begin{array}{l}\text { Simply-mad } \\
\text { e }\end{array}$ & $\begin{array}{l}\text { Formal data } \\
\text { table }\end{array}$ & $\begin{array}{l}\text { Proper use } \\
\text { of analysis } \\
\text { tools }\end{array}$ & $\begin{array}{l}\text { Reasonable } \\
\text { prediction } \\
\text { demand } \\
\text { resources } \\
\end{array}$ \\
\hline & $\begin{array}{l}\text { Rationality of contract } \\
\text { management } \\
\text { planningCb3 }\end{array}$ & $\begin{array}{l}\text { Simple } \\
\text { analysis }\end{array}$ & $\begin{array}{l}\text { Plan-making } \\
\text { procedurally }\end{array}$ & $\begin{array}{l}\text { Specific } \\
\text { methods } \\
\text { and tools }\end{array}$ & $\begin{array}{l}\text { Highlighted and } \\
\text { complete }\end{array}$ \\
\hline & $\begin{array}{l}\text { Approval rate for the } \\
\text { base plan on project } \\
\text { expense Cb4 }\end{array}$ & $\begin{array}{l}\geq 75 \% \\
\quad<80 \%\end{array}$ & $\geq 80 \%,\langle 85 \%$ & $\begin{array}{l}\geq 85 \% \\
\langle 90 \%\end{array}$ & $\geq 90 \%$ \\
\hline & $\begin{array}{l}\text { Completeness of the } \\
\text { quality assurance plan }\end{array}$ & $\begin{array}{l}\text { Simply-plan } \\
\text { ned }\end{array}$ & $\begin{array}{l}\text { Full } \\
\text { formatted }\end{array}$ & $\begin{array}{l}\text { Specific } \\
\text { methods }\end{array}$ & $\begin{array}{lr}\text { Scientific } & \text { and } \\
\text { feasible quality }\end{array}$ \\
\hline
\end{tabular}




\begin{tabular}{|c|c|c|c|c|c|}
\hline & Cb5 & & & and tools & standards \\
\hline & $\begin{array}{l}\text { Rationality of risk } \\
\text { planning Cb6 }\end{array}$ & $\begin{array}{l}\text { Simply-plan } \\
\text { ned }\end{array}$ & $\begin{array}{l}\text { Plan based } \\
\text { on research }\end{array}$ & $\begin{array}{l}\text { Specific } \\
\text { methods } \\
\text { and tools }\end{array}$ & $\begin{array}{l}\text { Highlighted and } \\
\text { complete }\end{array}$ \\
\hline & $\begin{array}{l}\text { Whether to establish a } \\
\text { reliable } \\
\text { system Cb7 }\end{array}$ & No & Yes & No & Yes \\
\hline & $\begin{array}{ll}\text { Rationality } & \text { of } \\
\text { confidentiality } & \\
\text { planning Cb8 } & \\
\end{array}$ & $\begin{array}{l}\text { Formal } \\
\text { documents }\end{array}$ & $\begin{array}{l}\text { Complete } \\
\text { confidentiali } \\
\text { ty plan }\end{array}$ & $\begin{array}{l}\text { Planned } \\
\text { procedurall } \\
\mathrm{y}\end{array}$ & Highlighted \\
\hline & $\begin{array}{l}\text { Correctness of the } \\
\text { formulation } \\
\text { technical baseline Cb9 }\end{array}$ & $\begin{array}{l}\text { Made by } \\
\text { individual }\end{array}$ & $\begin{array}{l}\text { Made and } \\
\text { studied by a } \\
\text { team }\end{array}$ & $\begin{array}{l}\text { Complete } \\
\text { and } \\
\text { highlighted }\end{array}$ & $\begin{array}{l}\text { The coordinated } \\
\text { line of function, } \\
\text { production, } \\
\text { distribution }\end{array}$ \\
\hline & $\begin{array}{lr}\text { Rationality } & \text { of } \\
\text { procurement } & \text { planning } \\
\text { Cb10 } & \end{array}$ & $\begin{array}{l}\text { Formal } \\
\text { documents }\end{array}$ & $\begin{array}{l}\text { Planned } \\
\text { procedurally } \\
\text { with norms }\end{array}$ & Highlighted & $\begin{array}{l}\text { Coordinated } \\
\text { inter-project } \\
\text { procurement } \\
\text { planning } \\
\end{array}$ \\
\hline & $\begin{array}{lr}\text { Rationality } & \text { of } \\
\text { knowledge } & \\
\text { management planning } \\
\text { Cb11 }\end{array}$ & $\begin{array}{l}\text { Orally-plan } \\
\text { ned }\end{array}$ & $\begin{array}{l}\text { Formal } \\
\text { document }\end{array}$ & $\begin{array}{l}\text { Planned by } \\
\text { specific } \\
\text { tools }\end{array}$ & $\begin{array}{l}\text { Complete and } \\
\text { highlighted }\end{array}$ \\
\hline & $\begin{array}{l}\text { Success rate of initial } \\
\text { prototype trial Cc1 }\end{array}$ & $\begin{array}{l}\geq 60 \% \quad, \\
<70 \%\end{array}$ & $\geq 70 \%,\langle 80 \%$ & $\begin{array}{l}\geq 80 \% \\
\langle 90 \%\end{array}$ & $\geq 90 \%$ \\
\hline & $\begin{array}{lrr}\begin{array}{l}\text { Frequency of } \\
\text { technologies }\end{array} & \begin{array}{r}\text { key } \\
\text { and } \\
\text { knowledge } \\
\text { systems Cc2 }\end{array} & \text { entry } \\
\end{array}$ & $\begin{array}{l}\geq 15 \text { times } \\
\text { /year, } \\
<\quad 25 \text { times } \\
\text { /year } \\
\end{array}$ & $\begin{array}{l}\geq 25 \text { times } / \text { ye } \\
\text { ar, } \\
<35 \text { times } / y \\
\text { ear }\end{array}$ & $\begin{array}{l}\geq 35 \text { times } / y \\
\text { ear, } \\
<45 \text { times/ } \\
\text { year }\end{array}$ & $\geq 45$ times/year \\
\hline & $\begin{array}{l}\text { Number of technical } \\
\text { state changes (per year) } \\
\text { Cc3 }\end{array}$ & $>8, \leq 10$ & $>6, \leq 8$ & $>4, \leq 6$ & $\langle 4$ \\
\hline $\begin{array}{l}\text { Project } \\
\text { executi } \\
\text { on and }\end{array}$ & $\begin{array}{l}\text { Integrity of the } \\
\text { National Defense PM } \\
\text { Information System } \\
\text { Cc4 }\end{array}$ & $\begin{array}{l}\text { With } \\
\text { schedule, } \\
\text { cost, quality } \\
\text { systems }\end{array}$ & $\begin{array}{l}\text { With } \\
\text { schedule, } \\
\text { cost, quality, } \\
\text { technology, } \\
\text { safety, } \\
\text { confidentiali } \\
\text { ty systems }\end{array}$ & $\begin{array}{l}\text { All systems } \\
\text { in readiness }\end{array}$ & $\begin{array}{l}\text { Integrated } \\
\text { management of } \\
\text { project } \\
\text { information }\end{array}$ \\
\hline $\begin{array}{l}\text { control } \\
\text { capabil } \\
\text { ity }\end{array}$ & $\begin{array}{l}\text { Rationality of Risk } \\
\text { checklist Cc5 }\end{array}$ & $\begin{array}{l}\text { With simple } \\
\text { list }\end{array}$ & $\begin{array}{l}\text { Identify } \\
\text { risks } \\
\text { correctly }\end{array}$ & $\begin{array}{l}\text { Containing } \\
\text { various risk } \\
\text { areas }\end{array}$ & $\begin{array}{l}\text { Highlighting } \\
\text { typical risk areas }\end{array}$ \\
\hline & $\begin{array}{l}\text { Number of updates on } \\
\text { project schedule (per } \\
\text { year)Cc6 }\end{array}$ & $>7, \leq 9$ & $>5, \leq 7$ & $>3, \leq 5$ & $\langle 3$ \\
\hline & $\begin{array}{lr}\begin{array}{l}\text { Number } \\
\text { unreasonable }\end{array} & \begin{array}{r}\text { of } \\
\text { over- } \\
\text { expenditures }\end{array} \\
\text { occurrence Cc7 } & \text { ( per } \\
\text { year) } & \\
\end{array}$ & $>7, \leq 9$ & $>5, \leq 7$ & $>3, \leq 5$ & $\langle 3$ \\
\hline & $\begin{array}{l}\text { Number of security } \\
\text { checks Cc8 (per year) }\end{array}$ & $\geq 2, \quad\langle 4$ & $\geq 4, \quad<6$ & $\geq 6, \quad\langle 12$ & $\geq 12$ \\
\hline & $\begin{array}{ll}\text { Efficiency } & \text { of } \\
\text { acquisition Cc9 }\end{array}$ & Lower & Common & Higher & Very high \\
\hline & Pass rate of reliability & $\geq 80 \%$ & $\geq 85 \%,\langle 90 \%$ & $\geq 90 \%$ & $\geq 95 \%$ \\
\hline
\end{tabular}




\begin{tabular}{|c|c|c|c|c|c|}
\hline & check Cc10 & $\langle 85 \%$ & & $\langle 95 \%$ & \multirow[b]{2}{*}{$\geq 12$} \\
\hline & $\begin{array}{l}\text { Number of quality } \\
\text { checks Cc11 (per year) }\end{array}$ & $\geq 2, \quad\langle 4$ & $\geq 4, \quad\langle 6$ & $\geq 6, \quad\langle 12$ & \\
\hline & $\begin{array}{l}\text { Pass rate of type test } \\
\text { and check Cc12 }\end{array}$ & $\begin{array}{l}\geq 83 \% \\
\langle 88 \%\end{array}$ & $\geq 88 \%,\langle 93 \%$ & $\begin{array}{l}\geq 93 \% \\
\langle 98 \%\end{array}$ & $\geq 98 \%$ \\
\hline \multirow{7}{*}{$\begin{array}{l}\text { Project } \\
\text { closure } \\
\text { capabil } \\
\text { ity }\end{array}$} & $\begin{array}{l}\text { Punctuality of project } \\
\text { completion Cd1 }\end{array}$ & $\begin{array}{l}\geq 70 \%, \\
<75 \%\end{array}$ & $\geq 75 \%,\langle 80 \%$ & $\begin{aligned} & \geq 80 \% \\
&\langle 85 \% \\
&\end{aligned}$ & $\geq 85 \%$ \\
\hline & $\begin{array}{l}\text { Pass rate of accounting } \\
\text { of the project expense } \\
\text { Cd2 }\end{array}$ & $\begin{array}{l}\geq 80 \% \\
\langle 85 \%\end{array}$ & $\geq 85 \%,\langle 90 \%$ & $\begin{array}{l}\geq 90 \% \\
\langle 95 \%\end{array}$ & $\geq 95 \%$ \\
\hline & $\begin{array}{l}\text { Archiving level of key } \\
\text { knowledge } \\
\text { technology Cd3 }\end{array}$ & Lower & Common & Higher & Very high \\
\hline & $\begin{array}{lr}\text { Re-usage } & \text { rate } \\
\text { of information } \\
\text { management platform } \\
\text { Cd4 }\end{array}$ & $\begin{array}{l}\geq 60 \% \\
\langle 70 \%\end{array}$ & $\geq 70 \%,\langle 80 \%$ & $\begin{array}{l}\geq 80 \% \\
\langle 90 \%\end{array}$ & $\geq 90 \%$ \\
\hline & $\begin{array}{l}\text { Times of reusing with } \\
\text { the revised plan (per } \\
\text { year) Cd5 }\end{array}$ & $\geq 1, \quad\langle 3$ & $\geq 3, \quad\langle 5$ & $\geq 5, \quad\langle 7$ & $\geq 7$ \\
\hline & $\begin{array}{l}\text { Completeness of file } \\
\text { after project changes } \\
\text { Cd6 }\end{array}$ & Incomplete & $\begin{array}{l}\text { More } \\
\text { complete }\end{array}$ & Complete & Very complete \\
\hline & $\begin{array}{l}\text { Time of reuse the PM } \\
\text { experience } \mathrm{Cd} 7\end{array}$ & $\geq 1, \quad\langle 3$ & $\geq 3, \quad\langle 5$ & $\geq 5, \quad\langle 7$ & $\geq 7$ \\
\hline \multirow{6}{*}{$\begin{array}{l}\text { Compr } \\
\text { ehensiv } \\
\text { e PM } \\
\text { capabil } \\
\text { ity }\end{array}$} & \begin{tabular}{ll} 
Ratio of & \multicolumn{1}{c}{ project } \\
management & to unit \\
management & $\mathrm{Ce} 1$
\end{tabular} & $\begin{array}{l}\geq 40 \% \\
\quad\langle 50 \%\end{array}$ & $\geq 50 \%,\langle 60 \%$ & $\begin{array}{l}\geq 60 \% \\
\langle 70 \%\end{array}$ & $\geq 70 \%$ \\
\hline & $\begin{array}{l}\text { Times of the use of } \\
\text { PM tools and methods } \\
\text { Ce2 (per project) }\end{array}$ & $\geq 50, \quad\langle 100$ & $\geq 100, \quad\langle 150$ & $\geq 150,\langle 200$ & $\geq 200$ \\
\hline & $\begin{array}{l}\text { Ratio of archived } \\
\text { documents to all } \\
\text { documents Ce3 }\end{array}$ & $\begin{array}{l}\geq 30 \% \\
\langle 50 \%\end{array}$ & $\geq 50 \%,\langle 70 \%$ & $\begin{array}{l}\geq 70 \% \\
\langle 90 \%\end{array}$ & $\geq 90 \%$ \\
\hline & $\begin{array}{ll}\text { Rationality of the } \\
\text { correlation between } \\
\text { PM and strategic } \\
\text { planning Ce4 }\end{array}$ & $\begin{array}{l}\text { Simple } \\
\text { analysis }\end{array}$ & $\begin{array}{l}\text { Standard } \\
\text { analysis }\end{array}$ & $\begin{array}{l}\text { Qualitative } \\
\text { analysis }\end{array}$ & $\begin{array}{l}\text { Achieving } \\
\text { strategic } \\
\text { objectives } \\
\text { application } \\
\end{array}$ \\
\hline & $\begin{array}{l}\text { Ration of multi-project } \\
\text { management to all PM } \\
\text { in a unit Ce5 }\end{array}$ & $\begin{array}{l}\geq 20 \% \\
\langle 30 \%\end{array}$ & $\geq 30 \%,\langle 40 \%$ & $\begin{array}{l}\geq 40 \% \\
\langle 50 \%\end{array}$ & $\geq 50 \%$ \\
\hline & $\begin{array}{lr}\text { Rate of } & \text { resource } \\
\text { utilization } & \text { among } \\
\text { projects Ce6 } & \\
\end{array}$ & $\begin{array}{l}\geq 60 \% \\
<70 \%\end{array}$ & $\geq 70 \%,\langle 80 \%$ & $\begin{array}{l}\geq 80 \% \\
\quad<90 \%\end{array}$ & $\geq 90 \%$ \\
\hline
\end{tabular}

\section{The Evaluation Method System of the PM maturity in the National Defense Research Institute}

In view of the characteristics of the PM maturity evaluation problems and the existing comprehensive evaluation methods, the author uses the method of grey relational grade (GRG) and AHP to evaluate the PM maturity of the National Defense Research Institute which is called gray multi-level comprehensive evaluation method. [5] Together with the index system, it constitutes the evaluation model of PM maturity of the National Defense Research Institute. There are three reasons why this method is chose. First, the evaluation of the PM maturity of the National Defense 
Research Institute is a grey problem, for which the GRG analysis method is suitable. Secondly, the artificial neural network (ANN) and the fuzzy comprehensive evaluation (FCE) methods are generally used to evaluate a single object. In this paper, the evaluation index system has multiple indexes with multi-level. Thirdly, the AHP is recognized as subjective evaluation method while the GRG is objective evaluation method that combines the objective and subjective evaluation organically. It facilitates the success of overcoming the deficiencies caused by single evaluation method.

In this paper, the designed PMMM for the National Defense Research Institute rests upon a three-tier structural index system. According to the grey theory, the evaluation of the second-class index should be taken to the third-class index as the first-level grey evaluation. Then, the evaluation of the first-class index should be taken to the second-class index as the second-level grey evaluation. Therefore, a two-level with three tiers grey evaluation model is framed. As a result, the specific working procedures are arranged as follows:

\subsection{Establishment of Index Sets}

(a) First-class index: PM maturity of the National Defense Research Institute, M

(b) Second-class index:

$\mathrm{M}=$ \{Project start-up capability A, Project plan capability B, Project execution and control capability C, Project closure capability D, Comprehensive PM capability E\}.

(c) Third-class index:

$\mathrm{A}=\left\{\mathrm{C}_{\mathrm{a} 1}, \mathrm{C}_{\mathrm{a} 2}, \mathrm{C}_{\mathrm{a} 3}, \mathrm{C}_{\mathrm{a} 4}, \mathrm{C}_{\mathrm{a} 5}, \mathrm{C}_{\mathrm{a} 6}\right\} ; \mathrm{B}=\left\{\mathrm{C}_{\mathrm{b} 1}, \mathrm{C}_{\mathrm{b} 2}, \mathrm{C}_{\mathrm{b} 3}, \mathrm{C}_{\mathrm{b} 4}, \mathrm{C}_{\mathrm{b} 5}, \mathrm{C}_{\mathrm{b} 6}, \mathrm{C}_{\mathrm{b} 7}, \mathrm{C}_{\mathrm{b} 8}, \mathrm{C}_{\mathrm{b} 9}, \mathrm{C}_{\mathrm{b} 10}\right.$, $\left.\mathrm{C}_{\mathrm{b} 11}\right\} ; \mathrm{C}=\left\{\mathrm{C}_{\mathrm{c} 1}, \mathrm{C}_{\mathrm{c} 2}, \mathrm{C}_{\mathrm{c} 3}, \mathrm{C}_{\mathrm{c} 4}, \mathrm{C}_{\mathrm{c} 5}, \mathrm{C}_{\mathrm{c} 6}, \mathrm{C}_{\mathrm{c} 7}, \mathrm{C}_{\mathrm{c} 8}, \mathrm{C}_{\mathrm{c} 9}, \mathrm{C}_{\mathrm{c} 10}, \mathrm{C}_{\mathrm{c} 11}, \mathrm{C}_{\mathrm{c} 12}\right\} ; \mathrm{D}=\left\{\mathrm{C}_{\mathrm{d} 1}, \mathrm{C}_{\mathrm{d} 2}\right.$, $\left.\mathrm{C}_{\mathrm{d} 3}, \mathrm{C}_{\mathrm{d} 4}, \mathrm{C}_{\mathrm{d} 5}, \mathrm{C}_{\mathrm{d} 6}, \mathrm{C}_{\mathrm{d} 7}\right\} ; \mathrm{E}=\left\{\mathrm{C}_{\mathrm{e} 1}, \mathrm{C}_{\mathrm{e} 2}, \mathrm{C}_{\mathrm{e} 3}, \mathrm{C}_{\mathrm{e} 4}, \mathrm{C}_{\mathrm{e} 5}, \mathrm{C}_{\mathrm{e} 6}\right\}$ 。

\subsection{Set rating criteria for evaluation index}

Considering the utmost ability of one's mind, in this paper the pros and cons (recorded as Vij) of the evaluation index are divided into four grades, each of which is respectively assigned (graded) to $1,2,3,4$ points; When the index rank is between two adjacent grades, the corresponding score is 1.5 and 2.5, as shown in Table 3.

Table 3 The standard level quantization (Vij) score table

\begin{tabular}{|l|l|l|l|l|}
\hline $\begin{array}{l}\text { The } \\
\text { Maturity } \\
\text { Rank }\end{array}$ & $\begin{array}{l}\text { Standardized } \\
\text { management } \\
\text { Rank }\end{array}$ & $\begin{array}{l}\text { Standardized } \\
\text { management } \\
\text { Rank }\end{array}$ & $\begin{array}{l}\text { Quantitative } \\
\text { management } \\
\text { Rank }\end{array}$ & $\begin{array}{l}\text { System } \\
\text { Management } \\
\text { Rank }\end{array}$ \\
\hline $\begin{array}{l}\text { Index } \\
\text { score }\end{array}$ & $0-1$ & $1-2$ & $2-3$ & $3-4$ \\
\hline
\end{tabular}

\subsection{Determine the weight of evaluation index}

The weight of each index is shown in Table 1.

\subsection{Organize the scores of experts who give evaluation}

The number of the experts is set as $k(k=1,2, \ldots, p)$. Namely, the amount of experts is $p$. The author organized $p$ experts to score at No. S Project according to the evaluation index Vij rating criteria, and filled in the score table of experts' evaluation.

The score table of experts' evaluation is referred to Table 2. , and the expert score table is made in reference to Table 2 .

\subsection{Evaluate Sample Matrix}

The Evaluation Sample Matrix of No. S Project $\left(D^{(S)}\right)$ is obtained according to the experts' evaluation score table, i.e. the rating of No. S Project given by No. k experts in line with the evaluation index Vij. 


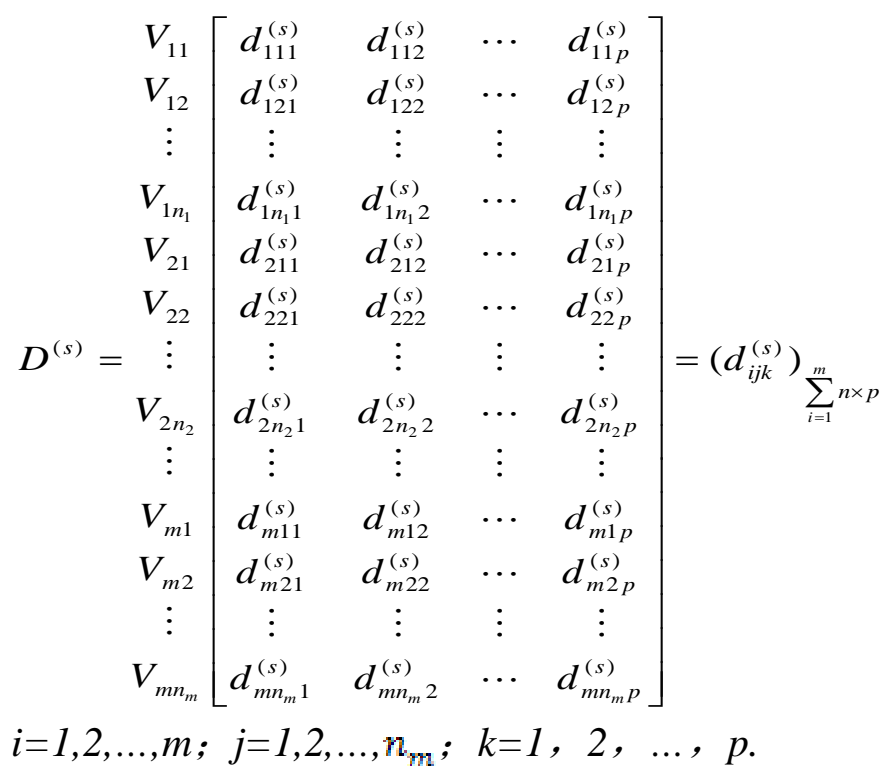

\subsection{Determine the Grey Class}

To determine the grey class is to determine the ranks of evaluation on grey class, grey number and the whitening function weight of grey number. We analyzed the above evaluation index Vij, decided to set 4 evaluation grey classes. The serial number of the grey class is e, namely e=1, 2, 3 , 4. Each of the serial number represents different ranks: "excellent”, "good”, “medium”, "poor”, and each corresponding whitening function weight is set as follows:

First grey class, "Excellent" $(e=1)$, grey number $\otimes_{1} \in[4, \infty)$, whitening function weight is $f_{1}$ (See Figure 2)

$f_{1}\left(d_{i j k}^{(s)}\right)=\left\{\begin{array}{cc}\frac{d_{i j k}^{(s)}}{4} & d_{i j k}^{(s)} \in[0,4] \\ 1 & d_{i j k}^{(s)} \in[4, \infty] \\ 0 & d_{i j k}^{(s)} \in[0, \infty]\end{array}\right.$

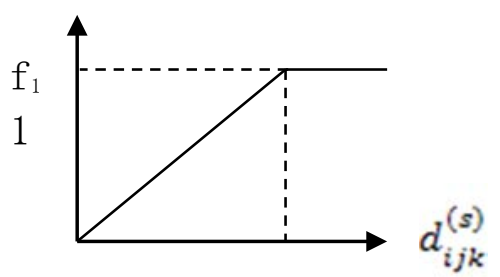

Figure 2 "Excellent”

Second grey class, "good" $(e=2)$, grey number $\otimes_{2} \in[0,3,6]$, whitening function weight is $f_{2}$ (See Figure 3)

$$
f_{2}\left(d_{i j k}^{(s)}\right)=\left\{\begin{array}{cc}
\frac{d_{i j k}^{(s)}}{3} & d_{i j k}^{(s)} \in[0,3] \\
\frac{d_{i j k}^{(s)}-6}{-3} & d_{i j k}^{(s)} \in[3,6] \\
0 & d_{i j k}^{(s)} \in[0,6]
\end{array}\right.
$$

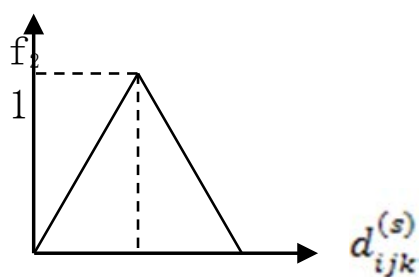

Figure $0 \quad 3 \quad 6$

Third grey class, "medium" ( $e=3$ ), grey number $\otimes_{3} \in[0,2,4]$, whitening function weight is $f_{3}$ (See Figure 4)

$$
f_{3}\left(d_{i j k}^{(s)}\right)= \begin{cases}\frac{d_{i j k}^{(s)}}{2} & d_{i j k}^{(s)} \in[0,2] \\ \frac{d_{i j k}^{(s)}-4}{-2} & d_{i j k}^{(s)} \in[2,4] \\ 0 & d_{i j k}^{(s)} \in[0,4]\end{cases}
$$

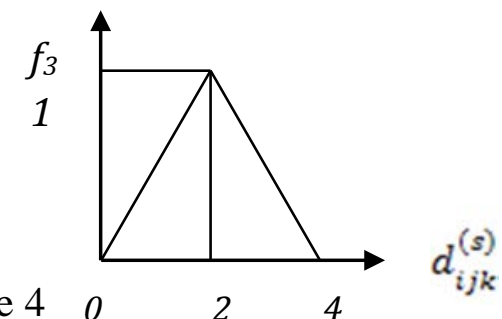

Third grey class, "poor" ( $e=4)$, grey number $\otimes_{4} \in[U, 1,2]$, whitening function weight is $f_{4}$ (See Figure 5). 


$$
f_{4}\left(d_{i j k}^{(s)}\right)= \begin{cases}1 & d_{i j k}^{(s)} \in[0,1] \\ \frac{d_{i j k}^{(s)}-2}{-1} & d_{i j k}^{(s)} \in[1,2] \\ 0 & d_{i j k}^{(s)} \in[0,2]\end{cases}
$$

Figure 5 "Poor"

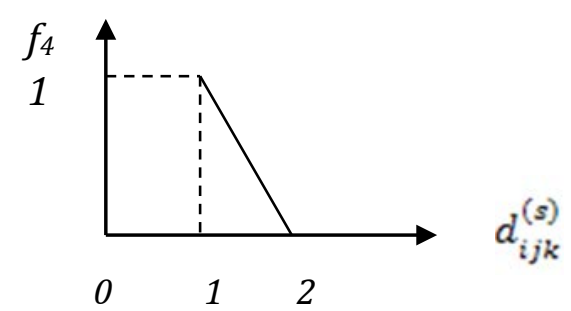

\subsection{Calculate grey evaluation coefficient}

For the evaluation index Vij, No. S. Project belongs to the grey evaluation coefficient of No. e. which is recorded as $x_{i j e}^{(s)}: \quad x_{i j e}^{(s)}=\sum_{k=1}^{p} f_{e}\left(d_{i j e}^{(s)}\right)$

For the evaluation index Vij, No. S. Project belongs to overall grey evaluation coefficient of each grey class evaluation which is recorded as $x_{i j}^{(s)}: \quad x_{i j}^{(s)}=\sum_{e=1}^{4} x_{i j e}^{(s)}$

\subsection{Calculate weight vector and weight matrix of grey evaluation}

According to the evaluation index Vij, towards No. S. Project, all experts claim the grey evaluation weight of No. e. to be $r_{i j e}^{(s)}: \quad r_{i j e}^{(s)}=\frac{x_{i j e}^{(s)}}{X_{i j}^{(s)}}$

Considering that there are four grey classes, i.e. $e=1,2,3,4$, here comes the evaluation index $\mathrm{Vij}$ of No. S. Project for each grey evaluation weight vectors, $r_{i j}^{(s)}$ :

$$
r_{i j}^{(s)}=\left(r_{i j 1}^{(s)}, r_{i j 2}^{(s)}, r_{i j 3}^{(s)}, r_{i j 4}^{(s)}\right)
$$

Then here comes the belonging index Vij of No. S. Project for grey evaluation weight matrix of each evaluation grey class: $R_{i}^{(s)}$ :

$$
R_{i}^{(s)}=\left[\begin{array}{c}
\boldsymbol{r}_{i 1}^{(s)} \\
\boldsymbol{r}_{i}(s) \\
\vdots \\
\boldsymbol{r i n}_{i}^{(s)}
\end{array}\right]=\left[\begin{array}{cccc}
r_{i 11}^{(s)} & r_{i 12}^{(s)} & r_{i 13}^{(s)} & r_{i 14}^{(s)} \\
r_{i 21}^{(s)} & r_{i 22}^{(s)} & r_{i 23}^{(s)} & r_{i 24}^{(s)} \\
\vdots & \vdots & \vdots & \vdots \\
r_{i n_{i} 1}^{(s)} & r_{i n_{i} 2}^{(s)} & r_{i n_{i} 3}^{(s)} & r_{i n_{i} 4}^{(s)}
\end{array}\right]
$$

\subsection{Comprehensive evaluation of $\mathrm{Vi}$}

Make comprehensive evaluation on Vi of No. S. Project. The comprehensive results are recorded as $B_{i}^{(s)}$, then: $\quad B_{i}^{(s)}=A_{i} \bullet R_{i}^{(s)}=\left(b_{i 1}^{(s)}, b_{i 2}^{(s)}, b_{i 3}^{(s)}, b_{i 4}^{(s)}\right)$

\section{10 Comprehensive evaluation of $U$}

From the comprehensive evaluation results of $V_{i,} B_{i}^{(s)}$, the grey evaluation weight matrix $R^{(s)}$ of No. S. Project's index, $U_{i}$ for each evaluation grey class is got.

$$
R^{(s)}=\left[\begin{array}{c}
B_{1}^{(s)} \\
B_{2}^{(s)} \\
\vdots \\
B_{m}^{(s)}
\end{array}\right]=\left[\begin{array}{cccc}
b_{11}^{(s)} & b_{12}^{(s)} & b_{13}^{(s)} & b_{14}^{(s)} \\
b_{21}^{(s)} & b_{22}^{(s)} & b_{23}^{(s)} & b_{24}^{(s)} \\
\vdots & \vdots & \vdots & \vdots \\
b_{m 1}^{(s)} & b_{m 2}^{(s)} & b_{m 3}^{(s)} & b_{m 4}^{(s)}
\end{array}\right]
$$

Afterwards, make a comprehensive evaluation on $U$ of No. S. Project. The comprehensive results are recorded as $B^{(S)}$. Then $\quad B^{(s)}=A \bullet R^{(s)}=\left(b_{1}^{(s)}, b_{2}^{(s)}, b_{3}^{(s)}, b_{4}^{(s)}\right)$ 


\subsection{Calculate the value of each second-class index and then analyze them}

Assigned grades to each grey class evaluation based on "Grey level." In other words, the First grey class "Excellent" is 4, the Second grey class "Good" is 3, the Third grey class "Medium" is 2, and the Fourth grey class "Poor" is 1 . Then, the vector quantity of each grey class evaluation C: $\mathrm{C}=(4,3,2,1)$

And, the evaluation grade of each aspects pertinent to the PM maturity of the National Defense Research Institute (i. e. the second-class index) $P_{i}^{(s)}$ :

$$
P_{i}^{(s)}=b_{i}^{(s)} \bullet C^{T}
$$

In this formulation, $\mathrm{i}=\{(1=\mathrm{A}),(2=\mathrm{B}),(3=\mathrm{C}),(4=\mathrm{D}),(5=\mathrm{E})\}, C^{T}$ is the transpose of graded-valued vectors for each grey class evaluation. After obtaining each second-class index $P_{i}^{(s)}$, it can be analyzed according to its position in Table 3.

\section{Conclusion}

In this paper, the author builds the evaluation index system, maturity rank, evaluation standard of PMMM for the National Defense Research Institute. Also, taking the method of gray multi-level comprehensive evaluation as model evaluation methods, it provides reference for the National Defense Research Institute to evaluate its PM maturity and increase the level of maturity. The author will further dig into the following two aspects. For one thing, it is necessary to better the evaluation index of PMMM for the National Defense Research Institute in combination with actual situation and the characteristics of the industry. For another, this paper only discusses the evaluation on PM maturity of the National Defense Research Institute, whereas PM for the National Defense Research Institute involves multifaceted, multi-level contents that should be further investigated in future study.

\section{Reference}

[1] Jiang Hancheng \& Qiang Maoshan. (2013). A comparative study of four project management maturity models. [J]. Project Management Technology. 7:17-22.

[2] Guo Yonghui, Shang Zhanwei, Zhou Junguo, Zhaotao. (2016). A review of key issues in group decision making. [J]. Decision Reference, 24 (016): 63-67.

[3] Shi Xueguang. (2017). Social impact assessment of river control engineering based on analytic hierarchy process [J]. Science and technology innovation, 26:183-184.

[4] Crawford, Kent. (2009). Maturity Model of project management. [M]. Beijing: Machinery Industry Press.

[5] Bai Sijun. (2009).Systems Engineering (2nd edition) [M]. Beijing: Machinery Industry Press. 